\title{
Preparation and Characterization of Hot-Pressed and Sintered BiPbSrCaCuO Superconductor
}

\author{
Mohamed Mohamed Ibrahim ${ }^{1}$, Nassar Mahmoud Megahid ${ }^{1}$, Mostafa Mohamed Abd El-Raheem², \\ Sayed Mohammed Khalil ${ }^{3}$ \\ ${ }^{1}$ Department of Physics, Faculty of Science, Sohag University, Sohag, Egypt; ${ }^{2}$ Department of Physics, Faculty of Science, Taif Uni- \\ versity, Taif, KSA; ${ }^{3}$ Department of Physics, Faculty of Science, Ummulqura University, Mekka, KSA. \\ Email: elneh@yahoo.com
}

Received December $23^{\text {rd }}, 2011$; revised January $24^{\text {th }}, 2012$; accepted February $9^{\text {th }}, 2012$

\begin{abstract}
Powder compacts of the system $\mathrm{Bi}_{2-\mathrm{x}} \mathrm{Pb}_{\mathrm{x}} \mathrm{Sr}_{2} \mathrm{Ca}_{2} \mathrm{Cu}_{3} \mathrm{O}_{\mathrm{y}}$ with $0 \leq \mathrm{x} \leq 0.5$ molar ratio using both techniques; isothermal hot pressing and the solid state reaction (sintering). The XRD of the hot pressed powder compacts of the nominal compositions $\mathrm{Bi}_{2-\mathrm{x}} \mathrm{Pb}_{\mathrm{x}} \mathrm{Sr}_{2} \mathrm{Ca}_{2} \mathrm{Cu}_{3} \mathrm{O}_{\mathrm{y}}$ showed 2212 and 2223 phases. The resistivity temperature variations belonging to the composition $\mathrm{Bi}_{1.8} \mathrm{~Pb}_{0.2} \mathrm{Sr}_{2} \mathrm{Ca}_{2} \mathrm{Cu}_{3} \mathrm{O}_{\mathrm{y}}$ showed metal-superconducting transition at $\mathrm{T}_{\text {ons }}=143 \mathrm{~K}$ for the annealed sample for 24 $\mathrm{h}$. The annealed nominal composition $\mathrm{Bi}_{1.5} \mathrm{~Pb}_{0.5} \mathrm{Sr}_{2} \mathrm{Ca}_{2} \mathrm{Cu}_{3} \mathrm{O}_{\mathrm{y}}$ for $18 \mathrm{~h}$ showed metal to superconducting transition at 80 $\mathrm{K}$.
\end{abstract}

Keywords: Electrical Resistivity; Superconductors; Hot Pressing; Sintering

\section{Introduction}

Podder et al. [1] have prepared the nominal compositions $\mathrm{Bi}_{1.7} \mathrm{~Pb}_{0.25} \mathrm{Sr}_{2} \mathrm{Ca}_{2} \mathrm{Cu}_{2} \mathrm{O}_{\mathrm{y}}$ and $\mathrm{Bi}_{1.5} \mathrm{~Pb}_{0.5} \mathrm{Sr}_{2} \mathrm{Ca}_{2} \mathrm{Cu}_{2} \mathrm{O}_{\mathrm{y}}$ using the conventional solid-state reaction method. PARK and IM [2] have prepared the system $\mathrm{Bi}_{0.7} \mathrm{~Pb}_{0.3} \mathrm{Sr}_{2} \mathrm{Ca}_{2} \mathrm{Cu}_{1.8} \mathrm{O}_{\mathrm{y}}$. The sol-gel method was used for preparation of high $\mathrm{T}_{\mathrm{c}}$ phase in the Bi-Pb-Sr-Ca-O system [3,4]. Accordingly [5], the $110 \mathrm{~K}$ single phase in $\mathrm{Pb}$-doped Bi-Sr-Ca-Cu-O system was prepared by the method of co-decomposition of nitrates. Pellets of the composition $\mathrm{Bi}_{1.7} \mathrm{~Pb}_{0.3} \mathrm{Sr}_{2} \mathrm{Ca}_{2} \mathrm{Cu}_{2} \mathrm{O}_{10}$, which was reported as the optimum composition for obtaining pure high $\mathrm{T}_{\mathrm{c}}$ phase in the $\mathrm{Bi}-\mathrm{Pb}-\mathrm{Sr}-\mathrm{Ca}-\mathrm{Cu}-\mathrm{O}$ system were prepared by thoroughly mixing $\mathrm{Bi}_{2} \mathrm{O}_{3}, \mathrm{PbO}$, $\mathrm{SrCO}_{3}, \mathrm{CaCO}_{3}$ and $\mathrm{CuO}$ [6]. Calcination and sintering with intermediate regrinding several times have been described [6]. Kanai et al. [7] used commercial powders of $3 \mathrm{~N}$ pure $\mathrm{Bi}_{2} \mathrm{O}_{3}, \mathrm{PbO}, \mathrm{SrO}, \mathrm{CaO}$ and $\mathrm{CuO}_{\mathrm{y}}$ and have obtained the 2212 phase with a small amount of the 2201 phase. Kawahara et al. [8,9] prepared the high $\mathrm{T}_{\mathrm{c}}$ superconductors $(\mathrm{Bi}, \mathrm{Pb})_{2} \mathrm{Sr}_{2} \mathrm{Ca}_{2} \mathrm{Cu}_{3} \mathrm{O}_{\mathrm{x}}$ by solid state reaction and ontaied the high $\mathrm{T}_{\mathrm{c}} 2223$. Bulk superconductors of $\mathrm{Bi}_{1.84} \mathrm{~Pb}_{0.34} \mathrm{Sr}_{1.91} \mathrm{Ca}_{2.03} \mathrm{Cu}_{2} \mathrm{O}_{3.06}$ were prepared by hotpressing sintering [10]. Noudem et al. $[11,12]$ have optimized a texting process of $\mathrm{Bi}-\mathrm{Pb}-\mathrm{Sr}-\mathrm{Cu}-\mathrm{O}$ (2223) superconducting ceramics by hot pressing. The $\mathrm{Pb}$ solubility of the 2212 and 2223 phases has been tested by Peter Majewski et al. [13]. Lidija et al. [14] demonstrated the ability of aerosol synthesis of multicomponent Bi-based high $T_{c}$ superconducting particles from pure nitrate solutions with improved compositional homogeneity all over the powder. Spherical solid Bi-Sr-Ca-O rich particles with the mean particle size around $400 \mathrm{~nm}$ were obtained from common nitrate solutions [14]. Glass-ceramic technology found to be a good method of obtaining $\mathrm{BiSrCa}-$ $\mathrm{CuO}$ superconductors [15], especially $(\mathrm{Bi}, \mathrm{Pb})_{2} \mathrm{Sr}_{2} \mathrm{CaCu}_{2} \mathrm{O}_{\mathrm{x}}$ phase forms well by this method.

Best superconducting properties found to be achieved at the temperature of annealing about $840^{\circ} \mathrm{C}-850^{\circ} \mathrm{C}$ [15]. Millera et al. [16] found that oxide $\mathrm{Bi}_{4} \mathrm{Sr}_{3} \mathrm{Ca}_{3} \mathrm{CuO}_{\mathrm{x}}$ and $\left(\mathrm{Bi}_{0.8}, \mathrm{~Pb}_{0.2}\right)_{4} \mathrm{Sr}_{3} \mathrm{Ca}_{3} \mathrm{Cu}_{4} \mathrm{O}_{\mathrm{x}}$ glasses, annealed above $470^{\circ} \mathrm{C}$, crystallize. The crystalline phases forming during annealing were, among others, oxide superconductors: $(\mathrm{Bi}$, $\mathrm{Pb})_{2} \mathrm{Sr}_{2} \mathrm{Cu}_{3} \mathrm{O}_{\mathrm{x}}\left(2201\right.$ with $\left.\mathrm{T}_{\mathrm{c}}=10 \mathrm{~K}\right),(\mathrm{Bi}, \mathrm{Pb})_{2} \mathrm{Sr}_{2} \mathrm{Ca}-$ $\mathrm{Cu}_{2} \mathrm{O}_{\mathrm{x}}\left(2212, \mathrm{~T}_{\mathrm{c}} 85 \mathrm{~K}\right)$, and $\left(\mathrm{Bi}, \mathrm{Pb}_{2} \mathrm{Sr}_{2} \mathrm{Ca}_{2} \mathrm{Cu}_{3} \mathrm{O}_{\mathrm{x}}(2223\right.$, $\mathrm{T}_{\mathrm{c}} 105 \mathrm{~K}$ ). The composition $\mathrm{Bi}_{1.6} \mathrm{~Pb}_{0.4} \mathrm{Sr}_{2} \mathrm{Ca}_{2} \mathrm{Cu}_{3} \mathrm{O}_{\mathrm{y}}$ was prepared, the super conducting transition temperatures found to be $103 \mathrm{~K}, 111 \mathrm{~K}$ and $110 \mathrm{~K}$ depending on the condition of preparation [17]. $\mathrm{Bi}(\mathrm{Pb})-\mathrm{Sr}-\mathrm{Ca}-\mathrm{Cu}-\mathrm{O}$ thin films have been prepared using Nd-YAG pulsed lase ablation on $\mathrm{Mg}$ substrate [18], it was found that increasing of the annealing temperature to $870^{\circ} \mathrm{C}$ and $880^{\circ} \mathrm{C}$ led to increasing the intensity of $T_{c}$ phase and the appearance of semiconducting phase.

\section{Experimental Technique}

Using bismuth oxide, strontium oxide, lead oxide and 
copper oxide of 99.99 purity have been used to prepare powder compacts of the system $\mathrm{Bi}_{2-\mathrm{x}} \mathrm{Pb}_{\mathrm{x}} \mathrm{Sr}_{2} \mathrm{Ca}_{2} \mathrm{Cu}_{3} \mathrm{O}_{\mathrm{y}}$ with $0 \leq \mathrm{x} \leq 0.5$ molar ratio using both techniques; isothermal hot-pressing and the solid state reaction (sintering). Appropriate weights of the route compounds satisfying a certain nominal composition were determined to the fourth decimal using an electrical analytical balance type (Fisher scientific XA 2000 DS) with sensitivity better than $10^{-4} \mathrm{gm}$. The pre-determined weight of the route compounds $\mathrm{Bi}_{2} \mathrm{O}_{3}, \mathrm{PbO}, \mathrm{SrO}, \mathrm{CuO}$ and $\mathrm{CaO}_{3}$ were mixed together in molar ratios 2 - x:x:2:2:2:3 which are convenient to satisfy preparation of nominal compositions of the system $\mathrm{Bi}_{2-\mathrm{x}} \mathrm{Pb}_{\mathrm{x}} \mathrm{Sr}_{2} \mathrm{Ca}_{2} \mathrm{Cu}_{3} \mathrm{O}_{\mathrm{y}}$ with $\mathrm{x}=0.1,0.2,0.3$, 0.4 and 0.5 . The method used for preparation of batches of powders was essentially based on that described previously elsewhere. The mixtures were dissolved in equivalent amount of Conc. $\mathrm{HNO}_{3}$. The solution was stirred and heated at $600^{\circ} \mathrm{C}$, until it becomes dry to form a precipitate with blue color. The blue product was then heated at $820^{\circ} \mathrm{C}$ for $24 \mathrm{~h}$, and then left to cool to room temperature, after that it was grinded and heated again at $820^{\circ} \mathrm{C}$ for another $24 \mathrm{~h}$, and then left to cool to room temperature. The product was then grinded thoroughly. Each of the five batches are corresponding to five differrent nominal compositions was divided into three parts. One part was used for preparing powder compacts by using hot-pressing technique. In this case, a pre-determined weight of the powder of the desired batches was directly charged into the die of the hot-pressing technique. Then it was isothermally hot-pressed at the temperature $845^{\circ} \mathrm{C}-850^{\circ} \mathrm{C}$ for $12 \mathrm{~h}$ under evacuation better than $10^{-3}$ torr, and under application of the uni-directional pressure of $5 \mathrm{ton} / \mathrm{cm}^{2}$. The outcomming compacts were cooled down to room temperature by shutting down the power of the furnace. The prepared tablets are clean and parallel and optically flat.

The x-ray diffraction examinations were carried out using Schemadzu x-ray diffractometer with $\mathrm{CuK} \alpha$ target.

The surface microstructure of the specimens were examined by means of a scanning electron microscope type Jeol JsM-5300 (Japan), where coating with an evaporated thin film of gold of $100 \AA$ thickness has been carried out to avoid building up of surface charges and reduce damage which might result from heating due to the incident electron beam.

The melting temperature, crystallization temperature and the transition width were studied using Shimadzu differential thermal analyzer system- 50 with heating rate $10^{\circ} \mathrm{C} \cdot \mathrm{min}^{-1}$.

The d.c electrical resistance of the prepared compacts was measured by means of the slandered four-terminal electrical resistivity method using a d.c stabilized power supply type F B impo, Gould Advance Beta digital multimeter, Keithely electrometer type $610 \mathrm{C}$ and d.c stabi- lized power supply type IRWIN.H.T power supply E.J134. The environmental temperature was monitored using copper-constantan thermocouple.

\section{Results \& Discussions}

\subsection{XRD Analysis}

For only hot-pressed powder compact of the nominal composition $\mathrm{Bi}_{2} \mathrm{Sr}_{2} \mathrm{Ca}_{2} \mathrm{Cu}_{3} \mathrm{O}_{y}$, the XRD proved that the most intense and the fourth intense phases could be identified as 2212 as shown in Figure 1(a). The second and fifth intense phases were also the same and could be identified as the high $T_{c}$ phase 2223. Two peaks with equal intensities, one is corresponding to the phase 2223 and the other is corresponding to the phase $2223+2212$ were appeared with appreciable intensity at $\mathrm{d}=2.7 \AA$ and $3.075 \AA$, both represent together the third intense phase. The phase $\mathrm{Bi}_{2} \mathrm{Sr}_{3} \mathrm{Cu}_{2} \mathrm{O}_{\mathrm{y}}$ could be observed. The nonsuperconducting phases $(\mathrm{Sr}, \mathrm{Ca}) \mathrm{CuO}_{2}$ could be identified and represents the less intense one on the diffracttogram.

For the nominal composition $\mathrm{Bi}_{1.9} \mathrm{~Pb}_{0.1} \mathrm{Sr}_{2} \mathrm{Ca}_{2} \mathrm{Cu}_{2} \mathrm{O}_{\mathrm{y}}$, the XRD shown in Figure 1(b) proving that the most intense, the second and the fifth intense phases are the same and could be identified as $\mathrm{Bi}_{1.6} \mathrm{~Pb}_{0.4} \mathrm{Sr}_{2} \mathrm{Ca}_{2} \mathrm{Cu}_{2} \mathrm{O}_{\mathrm{x}}$, the third intense phase was 2212 and the fourth intense one was 2223. Two unknown phases seemed existed and the non-superconducting phase $(\mathrm{Sr}, \mathrm{Ca}) \mathrm{CuO}_{2}$ could be identified with appreciable intensity.

For the nominal composition $\mathrm{Bi}_{1.8} \mathrm{~Pb}_{0.2} \mathrm{Sr}_{2} \mathrm{Ca}_{2} \mathrm{Cu}_{2} \mathrm{O}_{\mathrm{y}}$, the XRD shown in Figure 1(c) proving that the most intense, the fourth and the fifth intense phases were the same and could be identified as $\mathrm{Bi}_{1.6} \mathrm{~Pb}_{0.4} \mathrm{Sr}_{2} \mathrm{Ca}_{2} \mathrm{Cu}_{2} \mathrm{O}_{\mathrm{x}}$. The second intense phase could be identified as 2223 and the third one was 2212. Only one phase could not be identified. The nonsuperconducting phase $\mathrm{SrCuO}_{2}$ and $\mathrm{CaCuO}_{2}$ was entirely disappeared.

The XRD of the only hot-pressed nominal composition $\mathrm{Bi}_{1.7} \mathrm{~Pb}_{0.3} \mathrm{Sr}_{2} \mathrm{Ca}_{2} \mathrm{Cu}_{2} \mathrm{O}_{\mathrm{y}}$ shown in Figure 1(d), where the most intense phase 2212 can be identified. Two peaks with equal intensities, one corresponding to the phase 2212 and the second correspond to the phase 2223 could be identified and could be considered as the second intense phase. The third intense phase could be identified as $\mathrm{Bi}_{1.6} \mathrm{~Pb}_{0.4} \mathrm{Sr}_{2} \mathrm{Ca}_{2} \mathrm{Cu}_{2} \mathrm{O}_{\mathrm{y}}$. The fourth and the fifth intense phases could be identified respectively as 2212 and 2223 . Other non-superconducting phases containing and not containing $\mathrm{Pb}$ could be also identified which are namely $\mathrm{Ca}_{2} \mathrm{PbO}_{4}, \mathrm{Ca}_{2} \mathrm{CuO}_{3}$ and $(\mathrm{Sr}, \mathrm{Ca}) \mathrm{O}_{2}$ and $\mathrm{CaO}$. Meanwhile, the phases $\mathrm{Bi}_{2} \mathrm{Sr}_{3} \mathrm{Cu}_{2} \mathrm{O}_{\mathrm{y}}$ could be identified with an appreciable intensity.

As it is seen, the most frequent phase was 2223 . Besides, the phase 2212 which represents the most intense seemed existed with an appreciable abundancy. The less 
abundancy seemed belonging to the phase 2201 .

The XRD of the nominal composition

$\mathrm{Bi}_{1.6} \mathrm{~Pb}_{0.4} \mathrm{Sr}_{2} \mathrm{Ca}_{2} \mathrm{Cu}_{2} \mathrm{O}_{\mathrm{y}} \mathrm{Ca}_{2} \mathrm{Cu}_{2} \mathrm{O}_{\mathrm{y}}$ shown in Figure 1(e), where the most intense phase was the non-superconducting bi-oxide $\mathrm{Ca}_{2} \mathrm{CuO}_{3}$. The second and the third intense phases were the same and could be identified as 2234. The fourth and fifth intense phases were 2201 and 2212 respectively. So, it is obvious that the internal microstructure of this compact is quite different from all the other former ones. Other non-superconducting phases namely $\mathrm{SrCO}_{3}, \mathrm{Ca}_{2} \mathrm{PbO}_{3}, \mathrm{Ca}_{2} \mathrm{CuO}_{3}$ and $(\mathrm{Sr}, \mathrm{Ca}) \mathrm{CuO}_{2}$ with appreciable intensities could be identified.

It can be said that, the most frequent phase was 2223 . The non-superconducting phase are also frequent and with appreciable intensities.

The XRD of the last hot-pressed powder compact $\mathrm{Bi}_{1.5} \mathrm{~Pb}_{0.5} \mathrm{Sr}_{2} \mathrm{Ca}_{2} \mathrm{Cu}_{2} \mathrm{O}_{\mathrm{y}}$ shown in Figure 1(f), where the most intense phase was the low $\mathrm{T}_{\mathrm{c}} 2212$. The second, the

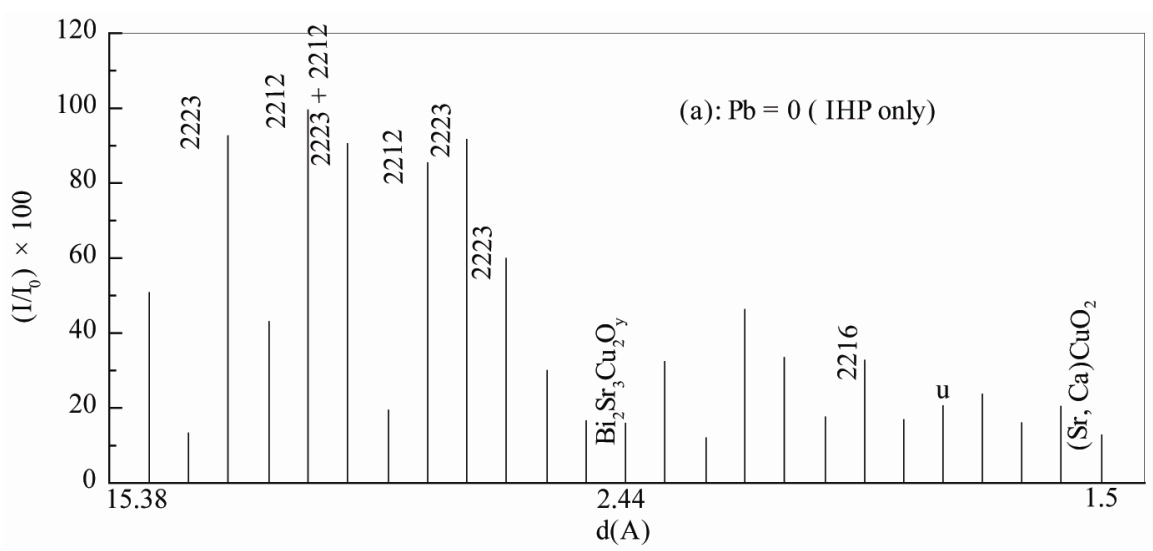

(a)

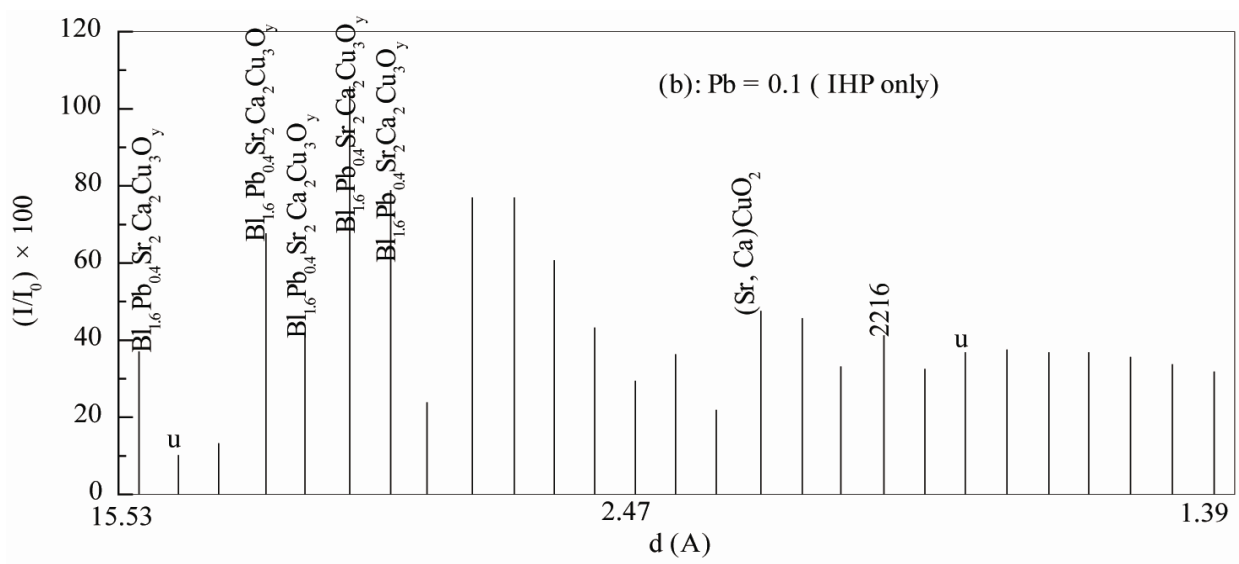

(b)

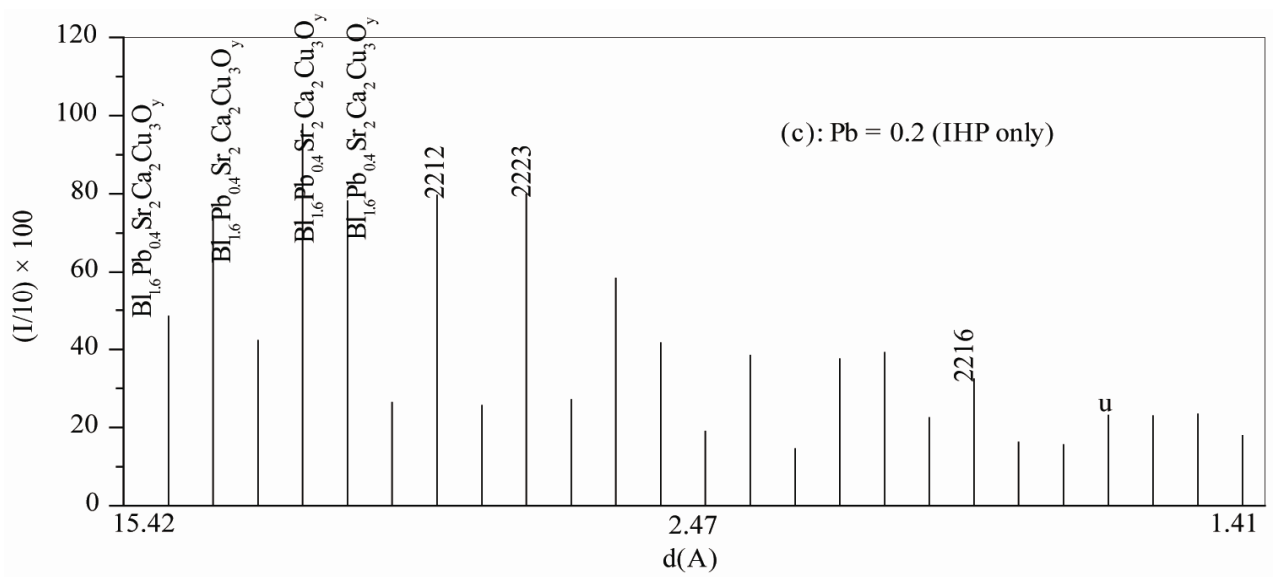

(c) 


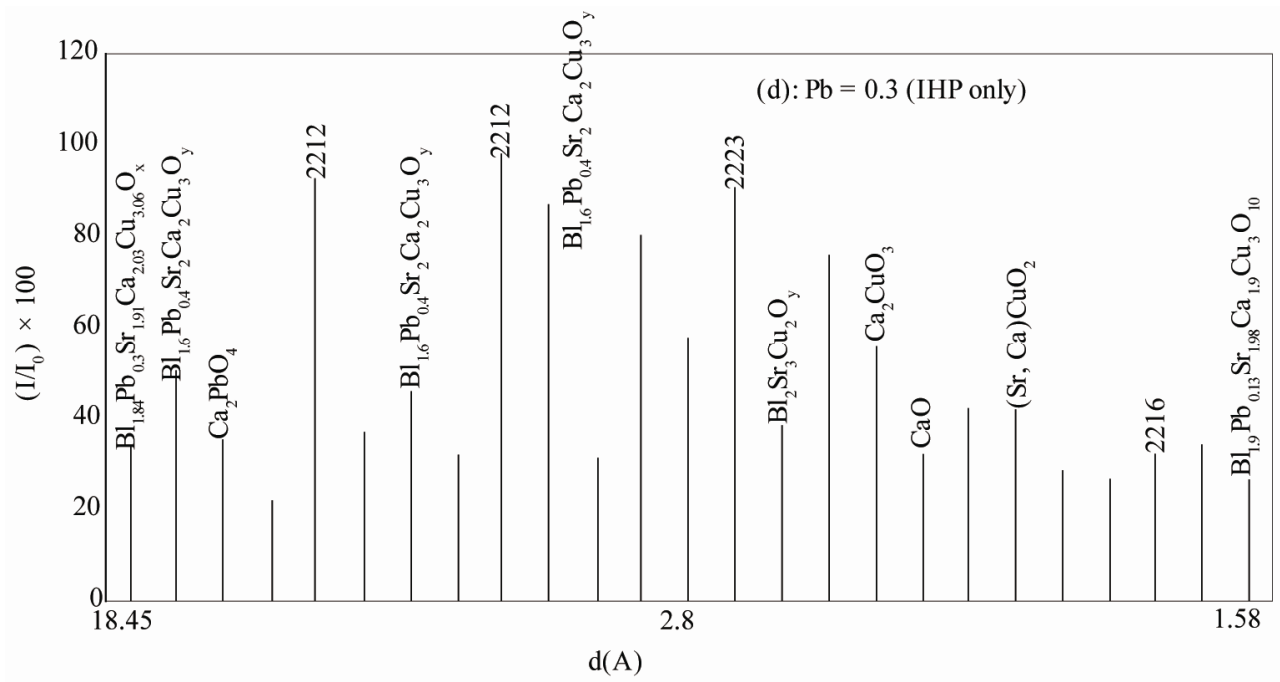

(d)

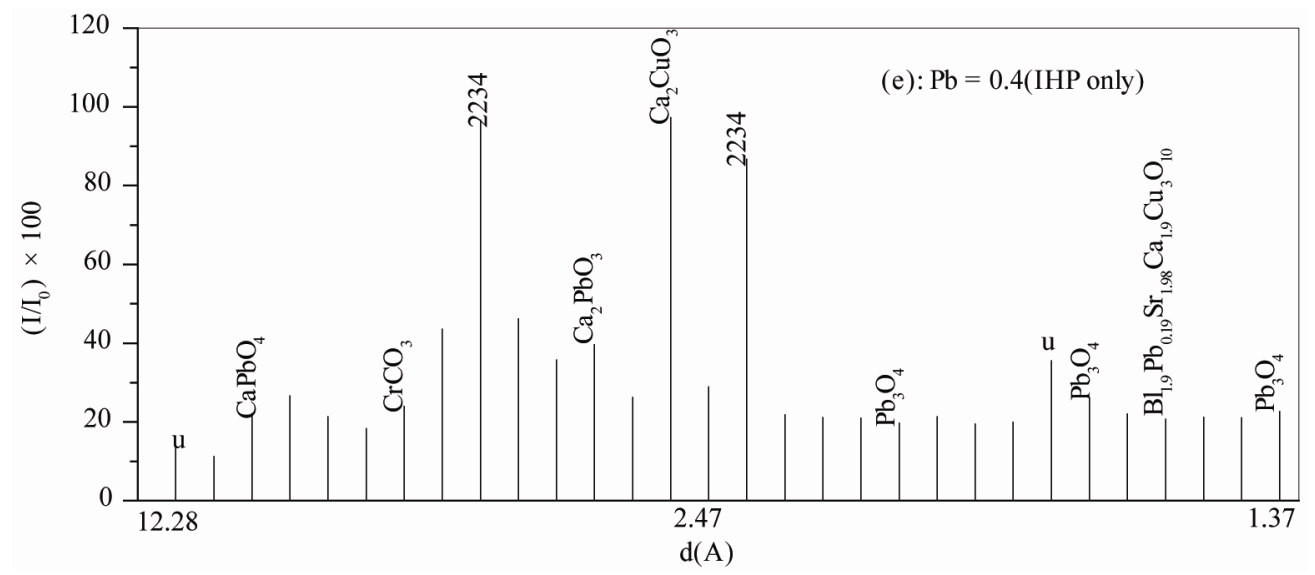

(e)

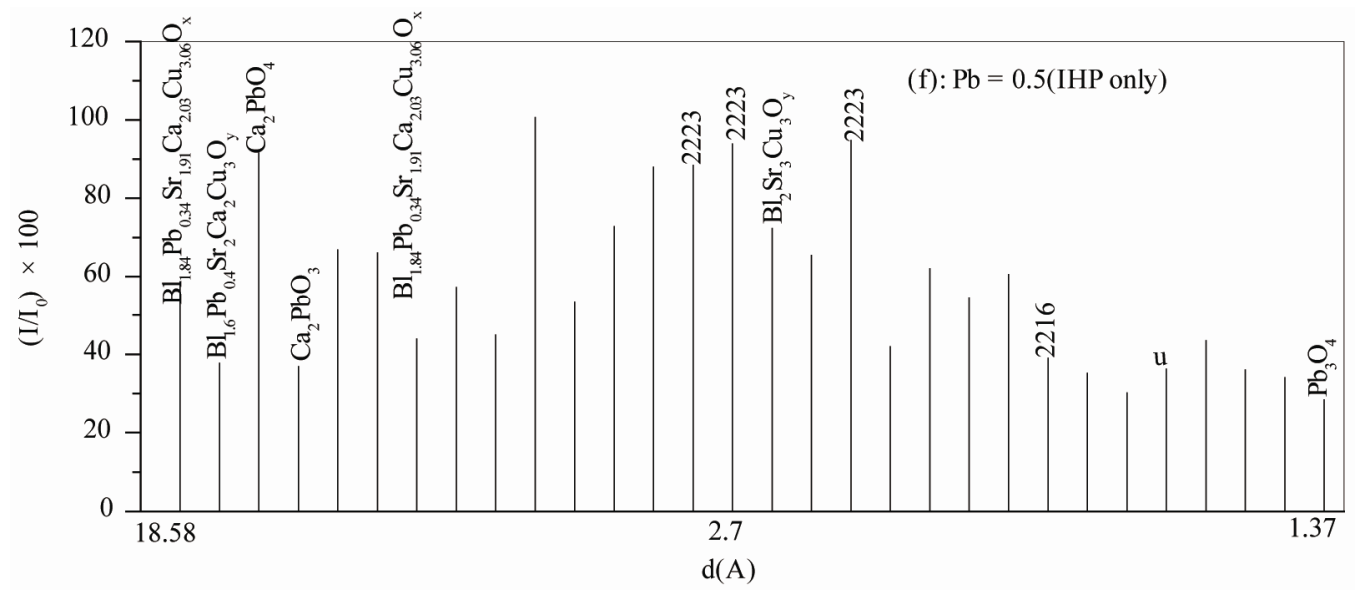

(f)

Figure 1. X-Ray diffractograms of IHP powder compacts of the compositions $\mathrm{Bi}_{2-\mathrm{x}} \mathrm{Pb}_{\mathrm{z}} \mathrm{Sr}_{2} \mathrm{Ca}_{2} \mathrm{Cu}_{3} \mathrm{O}_{\mathrm{y}}$.

third and the fifth intense phases were the same and could be identified as 2223. The fourth intense phase was the non-superconducting bi-oxide $\mathrm{Ca}_{2} \mathrm{PbO}_{4}$. The mixed phases $223+2212$ could be also identified. Also, the phase $\mathrm{Bi}_{2} \mathrm{Sr}_{3} \mathrm{Cu}_{2} \mathrm{O}_{\mathrm{y}}$ seemed existed with an appreciable intensity. The two phases $\mathrm{Bi}_{1.6} \mathrm{~Pb}_{0.4} \mathrm{Sr}_{2} \mathrm{Ca}_{2} \mathrm{Cu}_{2} \mathrm{O}_{\mathrm{y}}$ and $\mathrm{Bi}_{1.84} \mathrm{~Pb}_{0.34} \mathrm{Sr}_{1.91} \mathrm{Ca}_{2.03} \mathrm{Cu}_{2.06} \mathrm{O}_{\mathrm{y}}$ could be identified with appreciable intensities. The most frequent phases were 
2223 and 2212.

Comparing all the diffractograms on Figures 1(a-e), it is clear that the role of $\mathrm{Pb}$ content on the formed phases in the unified condition hot-pressed powder compacts of the system $\mathrm{Bi}_{2-\mathrm{x}} \mathrm{Pb}_{\mathrm{x}} \mathrm{Sr}_{2} \mathrm{Ca}_{2} \mathrm{Cu}_{3} \mathrm{O}_{\mathrm{y}}$ becomes clear. Both kinds and intensities of the phase seem depending strongly on the content of lead in the nominal compositions. Taking into account the three essential phases 223, 2212 and 2201 their maximum intensities changed with the content of $\mathrm{Pb}$ in the nominal compositions as shown in Figure 2. It is obvious that, both the high $\mathrm{T}_{\mathrm{c}} 223$ and low $\mathrm{T}_{\mathrm{c}} 2212$ phases could be existed in all the considered nominal compositions $0 \leq x \leq 0.5$. The very low $T_{c}$ phase 2201 could not be identified in nominal compositions containing less than $0.3 \mathrm{~Pb}$. In addition, the maximum intensity of both phases 223 and 2212 changed in similar manner with enriching with $\mathrm{Pb}$ over the whole considered molar ratio of $\mathrm{Pb}$.

For isothermally sintered (IS) powder compacts of the nominal compositions of the system $\mathrm{Bi}_{2-\mathrm{x}} \mathrm{Pb}_{\mathrm{x}} \mathrm{Sr}_{2} \mathrm{Ca}_{2} \mathrm{Cu}_{3} \mathrm{O}_{\mathrm{y}}$ then post-annealed (IPA) at $800^{\circ} \mathrm{C}$ for $30 \mathrm{~h}$, the $\mathrm{x}$-ray diffractograms were as shown in Figure 2.

For the nominal composition $\mathrm{Bi}_{2} \mathrm{Sr}_{2} \mathrm{Ca}_{2} \mathrm{Cu}_{3} \mathrm{O}_{\mathrm{y}}$, the most intense phase was the 2223. The other four successive intense phases were 2212. Two phases were appeared $\mathrm{Bi}_{2} \mathrm{Sr}_{3} \mathrm{Cu}_{2} \mathrm{O}_{\mathrm{y}}$ and $\mathrm{Bi}_{2} \mathrm{Sr}_{2} \mathrm{CuO}_{6}$.

\subsection{DTA Analysis}

For the as hot-pressed samples of the nominal composi- tions of the system $\mathrm{Bi}_{2} \mathrm{Sr}_{2} \mathrm{Ca}_{2} \mathrm{Cu}_{2} \mathrm{O}_{\mathrm{y}}$, the DTA thermogram was as shown in Figure 3 revealing no-exothermic peaks could be detected. Besides, it contained two endothermic peaks with at $430^{\circ} \mathrm{C}$ and $866.86^{\circ} \mathrm{C}$. The low endo-thermic temperature which can be attributed to partial melting increased continuously with enriching with $\mathrm{Pb}$ as shown in Figure 4 where the endothermic peaks were at $796.49^{\circ} \mathrm{C}$ and $925.46^{\circ} \mathrm{C}$ respectively.

\subsection{Electrical Properties}

The temperature dependences of the electrical resistivity of both hot-pressed and post annealed powder compacts are as shown in Figure 5.

The as-hot pressed powder compacts behaved similar to normal semiconductors. For $6 \mathrm{~h}$ of annealing at $800^{\circ} \mathrm{C}$ for $30 \mathrm{~h}$, the behavior was still that of semiconductor in the range above $93 \mathrm{~K}$. At $\mathrm{T}=93 \mathrm{~K}$, semiconductor to semimetal transition occurred and considered as an onset temperature $\mathrm{T}_{\text {ons }}$, and the resistivity felled very sharply with decreasing the temperature predicting of attaining the zero-resistance state at $T_{c}=77 \mathrm{~K}$. Prolongating the time of post-annealing to $12 \mathrm{~h}$, the behavior became similar to that of metals over the whole range considered for T. Despite transition to superconducting state did not hold, instead, the extrapolation to $0 \mathrm{~K}$ gave value for the residual resistivity $0.02 \mathrm{ohm}-\mathrm{cm}$. More prologation of post-annealing to $18 \mathrm{~h}$ resulted in drastic decrease of the compact's resistivity. The extrapolation to $0 \mathrm{~K}$ gave value for the resisdual resistivity $0.012 \mathrm{ohm}-\mathrm{cm}$. At $24 \mathrm{~h}$ of

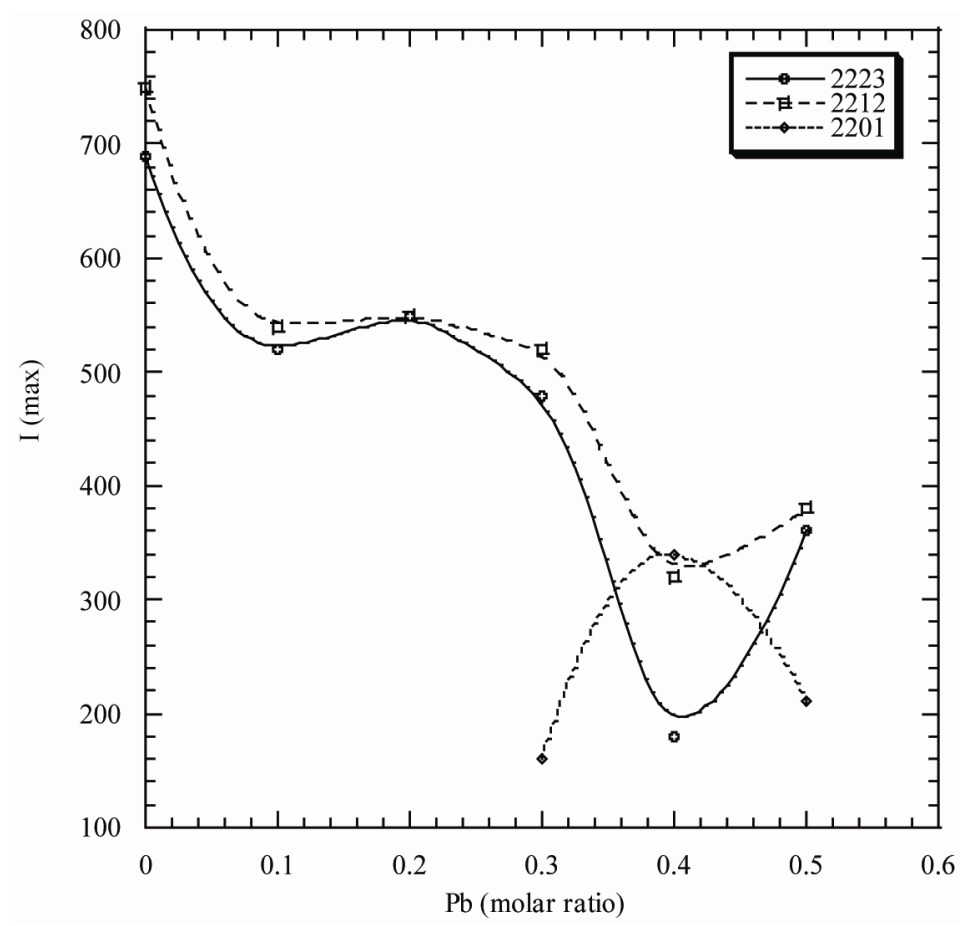

Figure 2. Variations of the maximum intensity of the phases 2223, 2212 and 2201 on the molar ratio of Pb in the only hotpressed compacts of the nominal compositions of the system $\mathrm{Bi}_{2-x \backslash n} \mathrm{~Pb}_{\mathrm{x}} \mathrm{Sr}_{2} \mathrm{Ca}_{2} \mathrm{Cu}_{3} \mathrm{O}_{\mathrm{y}}$. 


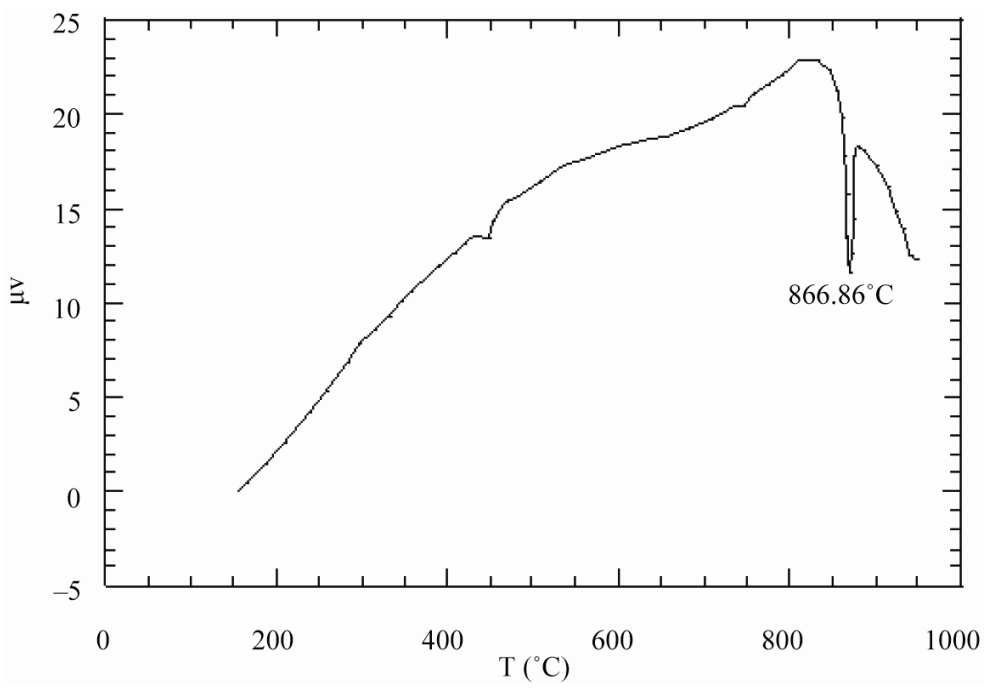

Figure 3. DTA thermogram of only hot-pressed powder compact of the nominal composition $\mathrm{Bi}_{2} \mathrm{Sr}_{2} \mathrm{Ca}_{2} \mathrm{Cu}_{2} \mathrm{O}_{\mathrm{y}}$.

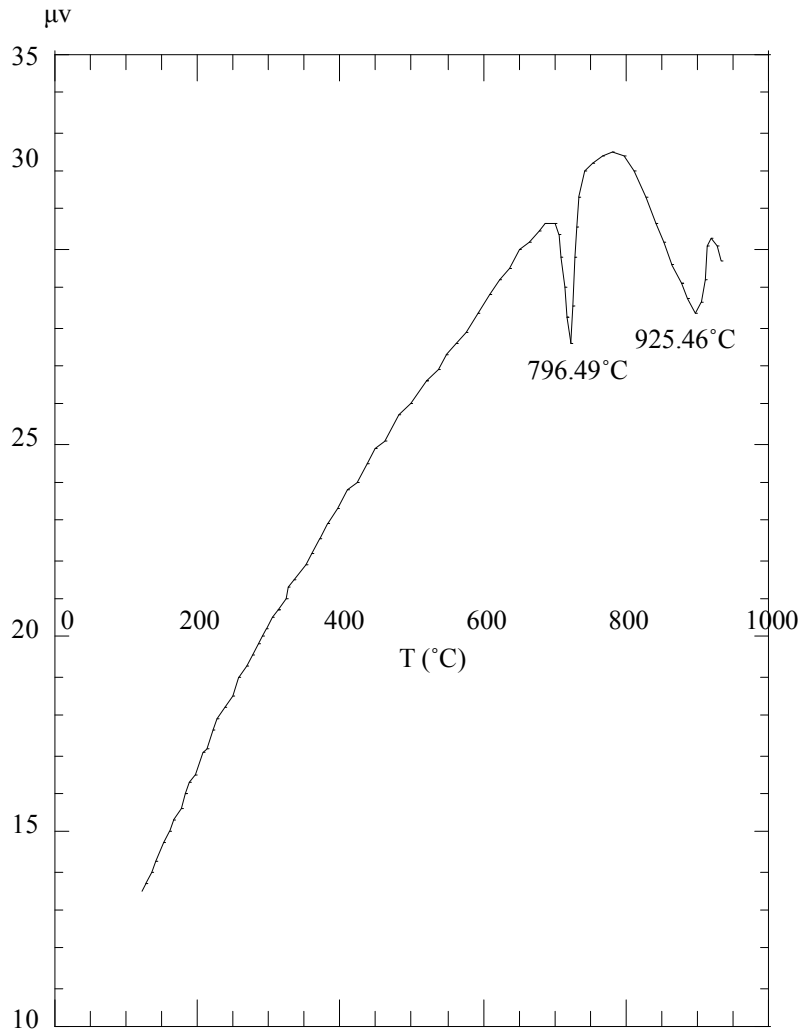

Figure 4. DTA thermogram of only IHP powder compact of the nominal composition $\mathrm{Bi}_{1.8} \mathrm{~Pb}_{0.2} \mathrm{Sr}_{2} \mathrm{Ca}_{2} \mathrm{Cu}_{3} \mathrm{O}_{\mathrm{y}}$.

post-annealing, the resistivity-temperature curve seemed similar to the case $18 \mathrm{~h}$. The extrapolation to $0 \mathrm{~K}$ gave value of residual resistivity $0.035 \mathrm{ohm}-\mathrm{cm}$.

From above, it can be said that, the nominal composition $\mathrm{Bi}_{2} \mathrm{Sr}_{2} \mathrm{Ca}_{2} \mathrm{Cu}_{3} \mathrm{O}_{\mathrm{y}}$ is not convenient to attain a single superconducting phase.

Addition of lead forming the composition
$\mathrm{Bi}_{1.9} \mathrm{~Pb}_{0.1} \mathrm{Sr}_{2} \mathrm{Ca}_{2} \mathrm{Cu}_{3} \mathrm{O}_{\mathrm{y}}$ resulted in temperature dependences of resistivity of as-hot pressed and post-annealed powder compacts as shown in Figure 6. The behavior of the as-hot pressed compact was that of semiconductors. Different successive transitions could be observed when post-annealing was carried out for the periods 6 and $12 \mathrm{~h}$. The resistivity decreased continuously with decreasing temperature for longer post-annealing times. Transition to superconducting state could not be held at all. Instead, the extrapolations to $0 \mathrm{~K}$ predicted values for the residual resistivity equal to $0.227,0.2,0.053,0.01$ and 0.048 ohm-cm.

So, the nominal composition $\mathrm{Bi}_{1.8} \mathrm{~Pb}_{0.2} \mathrm{Sr}_{2} \mathrm{Ca}_{2} \mathrm{Cu}_{3} \mathrm{O}_{\mathrm{y}}$ can not result in formation of superconducting phase.

Hot-pressed and post-annealed powder compacts containing $0.2 \mathrm{~Pb}$ possessed temperature dependences of resistivity as shown in Figure 6.

It is observed that, enriching with $\mathrm{Pb}$ to be resulted in a drastic decrease in the values of resistivity of the only hot-pressed compact. At $6 \mathrm{~h}$ post-annealing, semiconductor-semimetallic transition occurred at $103 \mathrm{~K}$. The residual resistivity belonging to the annealing times 12 , 18,24 and $30 \mathrm{~h}$ are $0.019,0.004,0.004$ and $0.012 \mathrm{ohm}-$ $\mathrm{cm}$ respectively.

From above, hot-pressing and post-annealing of powder compacts of the nominal composition $\mathrm{Bi}_{1.8} \mathrm{~Pb}_{0.2} \mathrm{Sr}_{2} \mathrm{Ca}_{2} \mathrm{Cu}_{3} \mathrm{O}_{\mathrm{y}}$ did not result in superconducting transition.

The temperature dependences of the electrical composition belonging to the nominal composition $\mathrm{Bi}_{1.7} \mathrm{~Pb}_{0.3} \mathrm{Sr}_{2} \mathrm{Ca}_{2} \mathrm{Cu}_{3} \mathrm{O}_{\mathrm{y}}$ are also comparable to those for the other former compositions. The extrapolations to $0 \mathrm{~K}$ of lowest temperature parts of the resistivity temperature curves, gave values for the residual resistivity equal to $0.0155,0.012,0.018$ and $0.017 \mathrm{ohm}-\mathrm{cm}$ for the times 12 , 18,24 and $30 \mathrm{~h}$ respectively. 


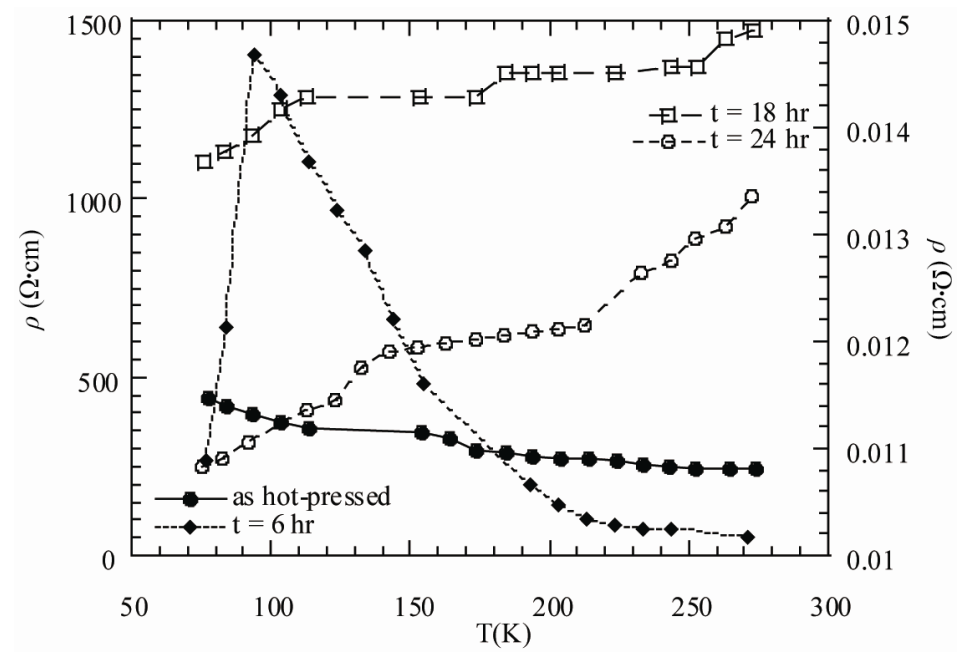

Figure 5. Resistivity-temperature dependence of as-hot-pressed and post-annealed for different times of the powder compacts of the nominal composition $\mathrm{Bi}_{2} \mathrm{Sr}_{2} \mathrm{Ca}_{2} \mathrm{Cu}_{3} \mathrm{O}_{\mathrm{y}}$.

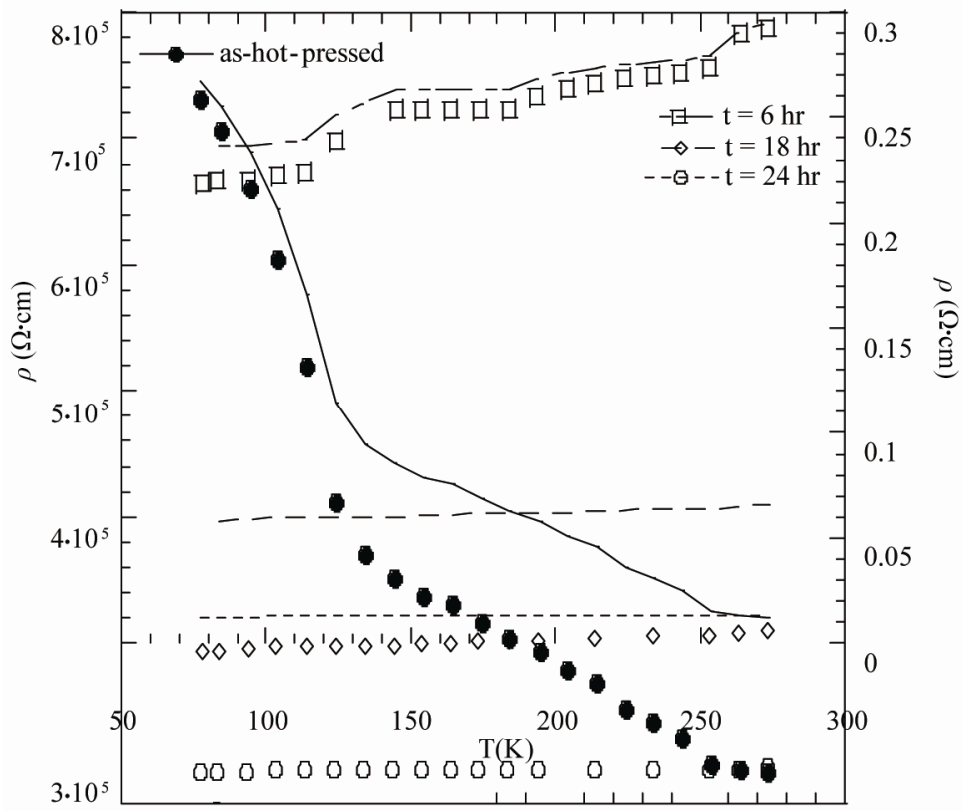

Figure 6. Resistivity-temperature dependence of the as-hot-pressed and post-annealed for different times of powder compacts of the nominal composition $\mathrm{Bi}_{1.8} \mathrm{~Pb}_{0.2} \mathrm{Sr}_{2} \mathrm{Ca}_{2} \mathrm{Cu}_{3} \mathrm{O}_{\mathrm{y}}$.

For the composition $\mathrm{Bi}_{1.6} \mathrm{~Pb}_{0.4} \mathrm{Sr}_{2} \mathrm{Ca}_{2} \mathrm{Cu}_{3} \mathrm{O}_{\mathrm{y}}$, the resistivity changed with temperature similar to the normal semiconductors.

It is clear that non of the later compacts show superconducting phase.

Figure 7 displays the relationship between the electrical resistivity versus the temperature for the

$\mathrm{Bi}_{1.5} \mathrm{~Pb}_{0.5} \mathrm{Sr}_{2} \mathrm{Ca}_{2} \mathrm{Cu}_{3} \mathrm{O}_{\mathrm{y}}$. The as-hot-pressed and post annealed for $6 \mathrm{~h}$ samples, the resistivity shows semiconductor-semimetallic transition at $124 \mathrm{~K}$. The post-annealed sample for $12 \mathrm{~h}$ exhibited semiconducting behavior over the whole range considered for T. Post-annealing for 18 ,
24 and $30 \mathrm{~h}$ resulted in semimetallic behavior over the whole range considered for $\mathrm{T}$. The extrapolation to $0 \mathrm{~K}$ predicted values for the residual resistivity equal to 0.01 , 0.111 , and $0.125 \mathrm{ohm}-\mathrm{cm}$ for the times of post annealing 18,24 and $30 \mathrm{~h}$ respectively.

As for the former compositions, addition of $\mathrm{Pb}$ can result in modification of the behavior of $\rho$-T dependence as well as in the values of resistivity.

The $\operatorname{Ln} \rho$ vs $1 / T$ relations belonging to the as-hotpressed and the post annealed samples found to be straight lines verifying the following relation

$$
\rho=\rho_{o} \mathrm{e}^{\mathrm{\Delta E} / \mathrm{kT}}
$$




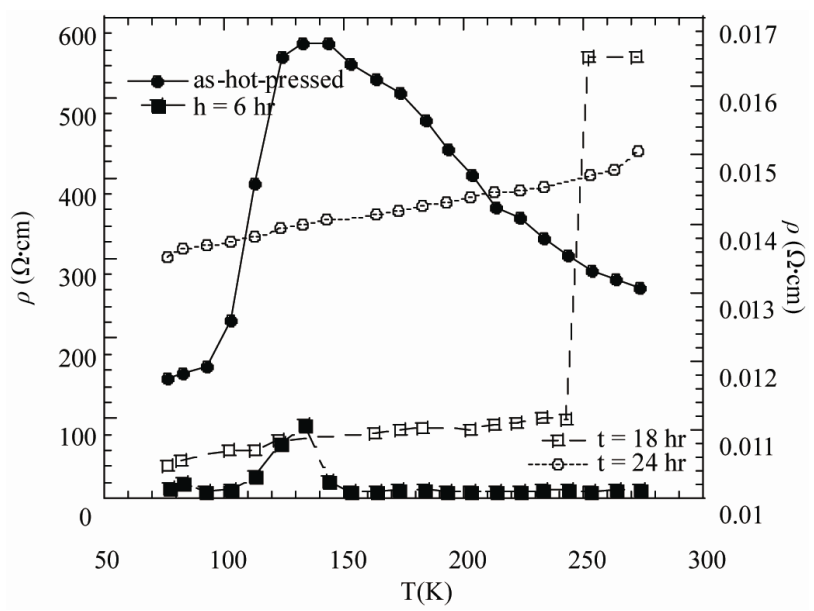

Figure 7. Resistivity-temperature dependence of the as-hotpressed and post-annealed for different times of powder compacts of the nominal composition $\mathrm{Bi}_{1.5} \mathrm{~Pb}_{0.5} \mathrm{Sr}_{2} \mathrm{Ca}_{2} \mathrm{Cu}_{3} \mathrm{O}_{\mathrm{y}}$.

where $\Delta \mathrm{E}$ is the activation energy of conduction, $\rho_{o}$ is the pre-exponential; $\mathrm{k}$ is the Boltzman's constant. Values of $\Delta \mathrm{E}$ are calculated and recorded in Table 1.

It is obvious that theses values of the electrical conduction activation energy are very small with respect to those recorded for normal semiconductors. On the other hand, the values of $\Delta \mathrm{E}$ decreased with transition from the higher to lower range of $\mathrm{T}$, except for those belonging to the annealed composition $\mathrm{Bi}_{1.8} \mathrm{~Pb}_{0.2} \mathrm{Sr}_{2} \mathrm{Ca}_{2} \mathrm{Cu}_{3} \mathrm{O}_{\mathrm{y}}$ for $6 \mathrm{~h}$. Meanwhile, the values of $\Delta \mathrm{E}=0.1579,0.2152$, $0.2377 \mathrm{EV}$ are comparable with those recorded for the narrow gap semiconductors.
The sintered samples of the nominal composition $\mathrm{Bi}_{2} \mathrm{Sr}_{2} \mathrm{Ca}_{2} \mathrm{Cu}_{3} \mathrm{O}_{\mathrm{y}}$, shows the temperature dependence of the electrical resistivity for both as-sintered and postannealed powder compacts which has the behavior of semiconductors. For the shortest period of post-annealing, $(6 \mathrm{~h})$, the behavior was similar to that for metals. Prolongating the time of annealing to $24 \mathrm{~h}$ results in superconducting transition with onset temperature $\mathrm{T}_{\text {ons }}=113.8$ $\mathrm{k}$ and the transition temperature $\mathrm{T}_{\mathrm{c}}=101.7 \mathrm{k}$ with transition width $\Delta \mathrm{T}=12.1 \mathrm{k}$. The reason of such transition may be revealed on referring the data of the microstructural analysis. However, from the first glimpse, it could be speculated that high concentration of the single 2223 or b2212 superconducting phase becomes existed in the compact. Furthermore, when the time of post-annealing was prolongated to $30 \mathrm{~h}$, the compact exhibited also metal to superconducting state transition at almost the same onset temperature as for the former case $T_{\text {ons }}=$ $110 \mathrm{k}$ and $\mathrm{T}_{\mathrm{c}}$ was almost the same and equal to $100 \mathrm{k}$ with $\Delta \mathrm{T}=10 \mathrm{k}$. Except, a tail appeared with $\mathrm{T}_{1}=40 \mathrm{k}$. This tail may be due to weak link between the grains of superconducting phases also may be due to un-expected intergrowth of non-superconducting phases. Both weak link and intergrowth processes can be regarded as collective reasons of the observed increase in resistivity (an order of magnitude) when the time of post annealing was prolongated from $24 \mathrm{~h}$ to $30 \mathrm{~h}$.

Addition of $0.1 \mathrm{~Pb}$ on the expense of $\mathrm{Bi}$ resulted in resistivity-temperature dependence which did not reveal any superconducting phase transition.

Table 1. Values of the activation energy $\Delta \mathrm{E}$ for as hot-pressed and post-annealed powder compacts of nominal compositions of the system $\mathrm{Bi}_{2-\mathrm{x}} \mathrm{Pb}_{\mathrm{x}} \mathrm{Sr}_{2} \mathrm{Ca}_{2} \mathrm{Cu}_{3} \mathrm{O}_{\mathrm{y}}$.

\begin{tabular}{|c|c|c|}
\hline Composition & Time of annealing (h) & $\Delta \mathrm{E}(\mathrm{EV})$ \\
\hline \multirow[t]{2}{*}{$\mathrm{Bi}_{2} \mathrm{Sr}_{2} \mathrm{Ca}_{2} \mathrm{Cu} 3 \mathrm{O}_{\mathrm{y}}$} & zero & $9.3 \times 10^{-5}, 4.9 \times 10^{-5}$ \\
\hline & 6 & $6.04 \times 10^{-4}, 1.3 \times 10^{-4}$ \\
\hline $\mathrm{Bi}_{1.9} \mathrm{~Pb}_{0.1} \mathrm{Sr}_{2} \mathrm{Ca}_{2} \mathrm{Cu}_{3} \mathrm{O}_{\mathrm{y}}$ & zero & $9.06 \times 10^{-3}, 3.07 \times 10^{-3}$ \\
\hline \multirow[t]{2}{*}{$\mathrm{Bi}_{1.8} \mathrm{~Pb}_{0.2} \mathrm{Sr}_{2} \mathrm{Ca}_{2} \mathrm{Cu}_{3} \mathrm{O}_{\mathrm{y}}$} & zero & $0.1579,0.0083$ \\
\hline & 6 & $0.0465,0.2152$ \\
\hline \multirow[t]{2}{*}{$\mathrm{Bi}_{1.7} \mathrm{~Pb}_{0.3} \mathrm{Sr}_{2} \mathrm{Ca}_{2} \mathrm{Cu}_{3} \mathrm{O}_{\mathrm{y}}$} & zero & $0.1095,0.0132$ \\
\hline & 6 & 0.0192 \\
\hline \multirow[t]{6}{*}{$\mathrm{Bi}_{1.6} \mathrm{~Pb}_{0.4} \mathrm{Sr}_{2} \mathrm{Ca}_{2} \mathrm{Cu}_{3} \mathrm{O}_{\mathrm{y}}$} & zero & $0.2377,0.03269,0.00406$ \\
\hline & 6 & $0.071,0.030$ \\
\hline & 12 & $0.078,0.038$ \\
\hline & 18 & $0.072,0.025$ \\
\hline & 24 & $0.078,0.024$ \\
\hline & 30 & $0.075,0.030$ \\
\hline \multirow[t]{3}{*}{$\mathrm{Bi}_{1.5} \mathrm{~Pb}_{0.5} \mathrm{Sr}_{2} \mathrm{Ca}_{2} \mathrm{Cu}_{3} \mathrm{O}_{\mathrm{y}}$} & zero & 0.0218319 \\
\hline & 6 & $0.003,0.106$ \\
\hline & 12 & $8.16 \times 10^{-3}, 5.51 \times 10^{-3}, 2.3 \times 10^{-3}$ \\
\hline
\end{tabular}


The $\rho$-T variation belonging to the composition $\mathrm{Bi}_{1.8} \mathrm{~Pb}_{0.2} \mathrm{Sr}_{2} \mathrm{Ca}_{2} \mathrm{Cu}_{3} \mathrm{O}_{\mathrm{y}}$ shows metal-superconducting transition at $\mathrm{T}_{\text {ons }}=143 \mathrm{k}$ for the annealed sample for $24 \mathrm{~h}$ as shown in Figure 8. Further, the zero-resistivity state could be attained at a high temperature $T_{c}=134 \mathrm{k}$ with transition width $\Delta \mathrm{T}=8.7 \mathrm{k}$. For the longest time considered for post-annealing $(30 \mathrm{~h})$, the electrical resistivity reach zero value at $T_{c}=79 \mathrm{k}$ as shown in Figure 8.

Enriching with lead of 0.3 and $0.4 \mathrm{~Pb}$ did not show any superconducting phase transitions.
The behavior of $\rho$-T belonging to the nominal composition $\mathrm{Bi}_{1.5} \mathrm{~Pb}_{0.5} \mathrm{Sr}_{2} \mathrm{Ca}_{2} \mathrm{Cu}_{3} \mathrm{O}_{\mathrm{y}}$ revealed that annealing for $18 \mathrm{~h}$ was accompanied with a metal to superconducting transition at $80 \mathrm{k}$ and the zero-resistivity state reached at $\mathrm{T}_{\mathrm{c}}=73.8 \mathrm{k}$.

Values of the activation energies for electrical conduction $\Delta \mathrm{E}_{\mathrm{s}}$ in the sintered powder compacts of the nominal composition $\mathrm{Bi}_{2-\mathrm{X}} \mathrm{Pb}_{\mathrm{x}} \mathrm{Sr}_{2} \mathrm{Ca}_{2} \mathrm{Cu}_{3} \mathrm{O}_{\mathrm{y}}$ have been obtained from the $\operatorname{Ln} \rho-1 / \mathrm{T}$ plots which found to be straight lines. Values of $\Delta \mathrm{E}_{\mathrm{s}}$ are recorded in Table 2.

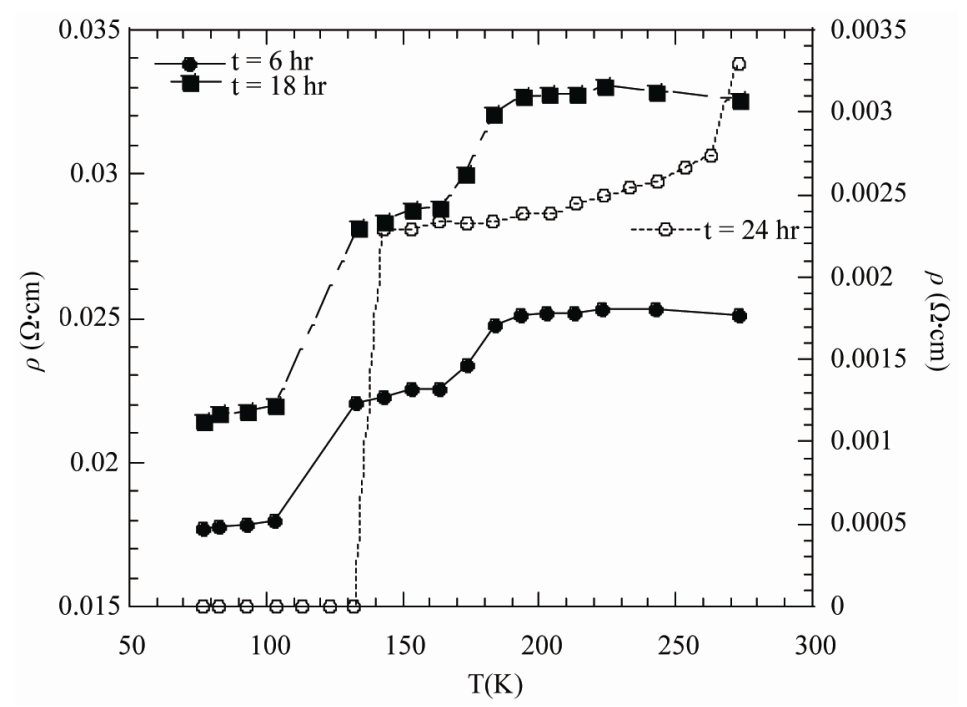

Figure 8. Resistivity-temperature dependence of the as-sintered and post-annealed for different times of powder compacts of the nominal composition $\mathrm{Bi}_{1.8} \mathrm{~Pb}_{0.2} \mathrm{Sr}_{2} \mathrm{Ca}_{2} \mathrm{Cu}_{3} \mathrm{O}_{\mathrm{y}}$.

Table 2. The values of the activation energy $\Delta \mathrm{E}_{\mathrm{s}}$ of the as-sintered and annealed compacts of the nominal composition of the system $\mathrm{Bi}_{2-\mathrm{x}} \mathrm{Pb}_{\mathrm{x}} \mathrm{Sr}_{2} \mathrm{Ca}_{2} \mathrm{Cu}_{3} \mathrm{O}_{\mathrm{y}}$.

\begin{tabular}{ccl}
\hline $\mathrm{Composition}$ & Annealing time (h) & \multicolumn{1}{c}{$\Delta \mathrm{E}_{\mathrm{s}}$} \\
\hline $\mathrm{Bi}_{2} \mathrm{Sr}_{2} \mathrm{Ca}_{2} \mathrm{Cu}_{3} \mathrm{O}_{\mathrm{y} .}$ & Zero & $0.009,0.0005$ \\
$\mathrm{Bi}_{1.9} \mathrm{~Pb}_{0.1} \mathrm{Sr}_{2} \mathrm{Ca}_{2} \mathrm{Cu}_{3} \mathrm{O}_{\mathrm{y} .}$ & 12 & 0.00004 \\
& 12 & $1.9 \times 10^{-6}$ \\
$\mathrm{Bi}_{1.8} \mathrm{~Pb}_{0.2} \mathrm{Sr}_{2} \mathrm{Ca}_{2} \mathrm{Cu}_{3} \mathrm{O}_{\mathrm{y} .}$ & 18 & $8.1 \times 10^{-7}$ \\
& $\mathrm{Zero}$ & $1.1 \times 10^{-4}, 7.8 \times 10^{-6}$ \\
& 12 & $1.4 \times 10^{-5}$ \\
& 18 & $1.2 \times 10^{-5}$ \\
$\mathrm{Bi}_{1.7} \mathrm{~Pb}_{0.3} \mathrm{Sr}_{2} \mathrm{Ca}_{2} \mathrm{Cu}_{3} \mathrm{O}_{\mathrm{y} .}$ & 30 & $4.5 \times 10^{-6}$ \\
& $\mathrm{Zero}$ & $5.9 \times 10^{-5}, 5.6 \times 10^{-4}, 3.3 \times 10^{-5}, 1.7 \times 10^{-3}, 5.8 \times 10^{-4}$ \\
& 6 & $1.07 \times 10^{-4}$ \\
$\mathrm{Bi}_{1.6} \mathrm{~Pb}_{0.4} \mathrm{Sr}_{2} \mathrm{Ca}_{2} \mathrm{Cu}_{3} \mathrm{O}_{\mathrm{y} .}$ & 18 & $6 \times 10^{-7}, 6.5 \times 10^{-6}, 9.7 \times 10^{-7}$ \\
& 30 & $1.4 \times 10^{-5}, 2.7 \times 10^{-6}, 1.3 \times 10^{-5}$ \\
& $\mathrm{Zero}$ & $0.309,0.139,9.7 \times 10^{-3}$ \\
& 6 & $0.085,0.022$ \\
$\mathrm{Bi}_{1.5} \mathrm{~Pb}_{0.5} \mathrm{Sr}_{2} \mathrm{Ca}_{2} \mathrm{Cu}_{3} \mathrm{O}_{\mathrm{y} .}$ & 12 & $0.05,6.5 \times 10^{-3}, 0.024$ \\
& 18 & $0.05,0.019,5.85 \times 10^{-3}, 0.042$ \\
& 24 & $0.045,0.015$ \\
\hline
\end{tabular}


It is obvious from the above table that, the activation energies belonging to the nominal composition $\mathrm{Bi}_{2-\mathrm{X}} \mathrm{Pb}_{\mathrm{x}} \mathrm{Sr}_{2} \mathrm{Ca}_{2} \mathrm{Cu}_{3} \mathrm{O}_{\mathrm{y}}$ possessed infinity small values with respect to those of normal semiconductors. On the other hand, the values of the activation energy are reduced much with transition from the higher to the lower range of dependence of resistivity on temperature.

\section{Conclusions}

1) Isothermal and hot pressing methods were used to prepare the system $\mathrm{Bi}_{2-\mathrm{x}} \mathrm{Pb}_{\mathrm{x}} \mathrm{Sr}_{2} \mathrm{Ca}_{2} \mathrm{O}_{\mathrm{y}}$.

2) From $x=0.0$ up to 0.5 , the isothermal hot pressed samples showed both semi metallic and semiconductor behaviors, whether the samples were as-prepared or post annealed.

3) Both high $T_{c} 2223$ and low $T_{c} 2212$ phases could be existed in the nominal compositions $0.0 \leq \mathrm{x} \leq 0.5$.

4) Sintered samples of the nominal composition $\mathrm{Bi}_{1.8} \mathrm{~Pb}_{0.2} \mathrm{Sr}_{2} \mathrm{Ca}_{2} \mathrm{Cu}_{3} \mathrm{O}_{\mathrm{y}}$ post annealed at $820^{\circ} \mathrm{C}$ for 24 hours showed zero resistivity at $\mathrm{T}_{\mathrm{c}}=134 \mathrm{~K}$. Other samples of the sintered one did not show any transition to zero resistivity.

\section{REFERENCES}

[1] A. Podder, P. Mandal, et al., "Electrical Resistivity, Magnetoresistance, Magnetisation, Hall Coefficient and Excess Conductivity in Pb-Doped Bi-Sr-Ca-Cu Oxides," Physsica C, Vol. 161, No. 5-6, 1989, pp. 567-573. doi:10.1016/0921-4534(89)90391-2

[2] S. Park, et al., "Sintering Period Dependence of Composition and Superconducting Properties of $(\mathrm{BiPb}) \mathrm{SrCaCu}_{1.8} \mathrm{O}_{\mathrm{x}}$ System," Journal of Materials Science, Vol. 25, No. 1, 1990, pp. 441-444. doi:10.1007/BF00714053

[3] A. Nozue, H. Nasu, Kanichi Kamiya and K. Tanaka, "Transport Characteristics Related with Microstructure of (Bi, Pb)-Sr-Ca-Cu-O Superconductor Prepared by the SolGel Method," Journal of Materials Science, Vol. 26, No. 16, 1991, pp. 4427-4432.

[4] K. Tanaka, A. Nozue and K. Kamiya, "Preparation of Bi, $\mathrm{Pb}-\mathrm{Sr}-\mathrm{Ca}-\mathrm{Cu}-\mathrm{O}$ Superconductor by the Sol-Gel Method," Journal of Materials Science, Vol. 25, No. 8, 1990, pp. 3551-3556. doi:10.1007/BF00575387

[5] N. L. Wang, et al., "Effect of Heat Treatment on the Superconductivity of $110 \mathrm{~K}$ Single Phase in the $\mathrm{Bi}(\mathrm{Pb})$ Sr-Ca-Cu-O System," Journal of Materials Science Letters, Vol. 10, No. 4, 1991, pp. 214-219.

doi: $10.1007 / \mathrm{BF} 00723808$

[6] A. Maqsood, M. Maqsood, M. S. Awan and N. Amin, "Appropriate Thermal Procedure for the Preparation of High-Tc Phase of $\mathrm{Bi}_{1.6} \mathrm{~Pb}_{0.4} \mathrm{Sr}_{2} \mathrm{Ca}_{2} \mathrm{Cu}_{3} \mathrm{O}_{\mathrm{y}}$ Superconductor," Journal of Materials Science, Vol. 26, No. 18, 1991, pp. 4893-4896.

[7] T. Kanai, T. Kamo, S. P. Matsuda and R. Shiobara,
"Properties of $\mathrm{Bi}(\mathrm{Pb})-\mathrm{Sr}-\mathrm{Ca}-\mathrm{Cu}-\mathrm{O}$ Superconductor Prepared by a Novel Oxidizing Solidification Process," Superconductor Science and Technology, Vol. 4, No. 4, 1991, p. 153.

[8] N. Kawahara, H. Enami, T. Sinohara, H. Hoshizaki, et al., "Destruction and Recovery of Superconductivity in $\mathrm{Bi}-\mathrm{Pb}-\mathrm{Sr}-\mathrm{Ca}-\mathrm{Cu}-\mathrm{O}$ Synthesized under High Pressure," Japanese Journal of Applied Physics, Vol. 31, No. 8, 1992, pp. 2427-2431. doi:10.1143/JJAP.31.2427

[9] N. Kobayashi, K. Egawa, K. Miyoshi, H. Iwasaki, H. Ikeda and R. Yoshizaki, "Fluctuation Effects in Specific Heat and Magnetization of $c$-Axis Aligned (Bi, $\mathrm{Pb})_{2} \mathrm{Sr}_{2} \mathrm{Ca}_{2} \mathrm{Cu}_{3} \mathrm{O}_{\mathrm{x}}$," Physica C: Superconductivity, Vol. 219, No. 3-4, 1994, pp. 265-272.

[10] G. Celotti, A. Tampieri, R. Musini and M. C. Malpezzi, "Evaluation of Structure-Related Parameters of HotPressed BISCCO (2223) Phase," Physica C: Superconductivity, Vol. 225, No. 3-4, 1994, pp. 346-352. doi:10.1016/0921-4534(94)90733-1

[11] A. Maqsood, M. Maqsood, M. S. Awan and N. Amin, "Appropriate Thermal Procedure for the Preparation of High-Tc Phase of $\mathrm{Bi}_{1.6} \mathrm{~Pb}_{0.4} \mathrm{Sr}_{2} \mathrm{Ca}_{2} \mathrm{Cu}_{3} \mathrm{O}_{\mathrm{y}}$ Superconductor," Journal of Materials Science, Vol. 26, 1991, pp. 4893-4896. doi:10.1007/BF00549867

[12] J. G. Noudem, J. Beille, D. Bourgault, A. Sulpice and R. Tournier, "Optimization of Texturing Process by Hot Pressing of Bi-Pb-Sr-Ca-Cu-O (2223) Ceramics," Physica C: Superconductivity, Vol. 230, No. 1-2, 1994, pp. 42-50. doi:10.1016/0921-4534(94)90444-8

[13] P. Majewski, S. Kaesce, H. Lung ang Su and F. Aldinger, "The $\mathrm{Pb}$ Solubility of the Bi-Based High-Tc Superconductors ' $\mathrm{Bi}_{2} \mathrm{Sr}_{2} \mathrm{CaCu}_{2} \mathrm{O}_{8}$ ' and ' $\mathrm{Bi}_{2} \mathrm{Sr}_{2} \mathrm{Ca}_{2} \mathrm{Cu}_{3} \mathrm{O}_{10}$ ' as a Function of Temperature," Physica C: Superconductivity, Vol. 221, No. 3-4, 1994, pp. 295-298. doi:10.1016/0921-4534(94)90235-6

[14] L. Mancic, O. Milosevic, N. Labus and M. Ristic, "High TC Superconducting Powders Synthesis from Aerosol," Journal of the European Ceramic Society, Vol. 21, No. 15, 2001, pp. 2765-2769. doi:10.1016/S0955-2219(01)00360-0

[15] M. Gasda, B. Kusz, S. Stizza, S. Cudinov, R. Natali, J. Pietosa and A. Bienias, "Conductivity and Superconductivity of $(\mathrm{Bi}, \mathrm{Pb})_{4} \mathrm{Sr}_{3} \mathrm{Ca}_{3} \mathrm{Cu}_{4} \mathrm{O}_{\mathrm{x}}$ Glass-Ceramics," Acta Physica Polonica A, Vol. 111, No. 5, 2007, pp. 713-719.

[16] W. Millera, K. Borowkoa, M. Gazda, S. Stizzab and R. Natalib, "Superconducting Properties of BiPbSrCeCuO and BiSrCaCuO Glass-Ceramics," Acta Physica Polonica $A$, Vol. 109, No. 4-5, 2006, pp. 627-631.

[17] P. R. Fernando and N. Pathmanathan, "Fabrications and Characterization of $\mathrm{Bi}_{1.6} \mathrm{~Pb}_{0.4} \mathrm{Sr}_{2} \mathrm{Ca}_{2} \mathrm{Cu}_{3} \mathrm{O}_{\mathrm{y}}$ Superconductors Prepared by Solid State Reaction Technique," Sri Lankan Journal of Physics, Vol. 7, 2006, pp. 7-13.

[18] A. N. Jannah, S. A. Halim and H. Abdullah, "Annealing Treatment of $\mathrm{Bi}(\mathrm{Pb})-\mathrm{Sr}-\mathrm{Ca}-\mathrm{Cu}-\mathrm{O}$ Thin Films on $\mathrm{MgO}$ by Pulsed Laser Deposition," Journal of Applied Sciences, Vol. 9, No. 11, 2009, pp. 2190-2193.

doi:10.3923/jas.2009.2190.2193 